\title{
Salegentibacter flavus sp. nov.
}

Correspondence

Elena P. Ivanova eivanova@swin.edu.au

\author{
Elena P. Ivanova, ${ }^{1,2}$ John P. Bowman, ${ }^{3}$ Richard Christen, ${ }^{4}$ \\ Natalia V. Zhukova, ${ }^{5}$ Anatoly M. Lysenko, ${ }^{6}$ Natalia M. Gorshkova, ${ }^{2}$ \\ Natasa Mitik-Dineva, ${ }^{1}$ Alexander F. Sergeev ${ }^{7}$ and Valery V. Mikhailov ${ }^{2}$ \\ ${ }^{1}$ Swinburne University of Technology, PO Box 218, Hawthorn, Victoria 3122, Australia \\ ${ }^{2}$ Pacific Institute of Bioorganic Chemistry of the Far-Eastern Branch of the Russian Academy \\ of Sciences, Pr. 100 Let Vladivostoku 159, Russia \\ ${ }^{3}$ Department of Agricultural Science, University of Tasmania, Hobart, Tasmania, Australia \\ ${ }^{4}$ UMR6543 CNRS - Université de Nice Sophia Antipolis, Centre de Biochimie, Parc Valrose \\ 06108 Nice cedex 2, France \\ ${ }^{5}$ Institute of Marine Biology of the Far-Eastern Branch of the Russian Academy of Sciences, \\ 690041 Vladivostok, Russia \\ ${ }^{6}$ Institute of Microbiology of the Russian Academy of Sciences, 117811 Moscow, Russia \\ ${ }^{7}$ Pacific Oceanological Institute of the Far-Eastern Branch of the Russian Academy of \\ Sciences, Baltiiskaya Str. 43, 690017 Vladivostok, Russia
}

The genus Salegentibacter, belonging to the family Flavobacteriaceae, was created to accommodate moderately halophilic, yellow-pigmented, non-gliding bacteria that were isolated from a hypersaline meromictic lake in Antarctica (McCammon \& Bowman, 2000). At the time of writing, the genus comprises three recognized species, Salegentibacter salegens (Dobson et al., 1993; McCammon \& Bowman, 2000), Salegentibacter holothuriorum (Nedashkovskaya et al., 2004) and Salegentibacter mishustinae (Nedashkovskaya et al., 2005). We report here the characterization and description of a novel Flavobacterium-like bacterium, strain $\mathrm{Fg} 69^{\mathrm{T}}$, isolated from a sediment sample collected in Chazhma Bay (Sea of Japan). On the basis of the results obtained, we propose that this organism be classified as a novel species of the genus Salegentibacter.

Abbreviation: FAMEs, fatty acid methyl esters.

The GenBank/EMBL/DDBJ accession number for the 16S rRNA gene sequence of strain $\mathrm{Fg} 69^{\top}$ is $\mathrm{AY} 682200$.
This work formed part of a taxonomic survey of free-living microbial populations of a coastal area of the north-west Pacific Ocean, where sediments have become contaminated by radionuclides as a result of an accident on a nuclear submarine. Sediment samples were collected from a subseafloor depth of $0.5 \mathrm{~m}$ in October-November 2000 from Chazhma Bay, Gulf of Peter the Great, Sea of Japan (Ivanova et al., 2005). Samples were kept at $4{ }^{\circ} \mathrm{C}$ and processed within 4-8 h. Sample handling and isolation procedures were as described elsewhere (Ivanova et al., 1996, 2004, 2005). Inoculated plates were incubated aerobically at room temperature (about $22-25^{\circ} \mathrm{C}$ ) for $5-10$ days. Strains were stored at $-80^{\circ} \mathrm{C}$ in marine broth 2216 (Difco) supplemented with $20 \%$ (v/v) glycerol.

Unless otherwise indicated, the phenotypic properties used for characterization of Flavobacterium-related species were tested following established procedures (McMeekin et al., 1971; Smibert \& Krieg, 1994; Ivanova et al., 1996; Bernardet et al., 2002). To test for spreading growth and gliding 
motility, strains were grown on medium B (Ivanova et al., $1996)$ with reduced peptone content $\left(0 \cdot 2 \mathrm{~g} \mathrm{l}^{-1}\right)$. Gliding motility was verified by using phase-contrast microscopy (Nikon) of hanging drop preparations. In order to detect flexirubin-type pigments, the bathochromic shift test utilizing $20 \%$ (w/v) KOH was used (Fautz \& Reichenbach, 1980). Cellulose hydrolysis was tested both by using cellulose overlay plates (1\% CM-cellulose) and by examining strips of filter paper in liquid bacterial cultures for dissolution (Smibert \& Krieg, 1994). The following physiological and biochemical properties were examined using the methods described by Smibert \& Krieg (1994): oxidation/fermentation of glucose; oxidase and catalase activity; gelatin liquefaction; sodium chloride requirement $[0,0 \cdot 5,1,3,6,8,10$ and $12 \%(\mathrm{w} / \mathrm{v}) \mathrm{NaCl}$; acetoin, urea, indole and $\mathrm{H}_{2} \mathrm{~S}$ production; and the ability to hydrolyse starch, Tween 80 and casein. Denitrification was assessed using the procedure of Azegami et al. (1987). Growth at different temperatures was tested in marine broth 2216 (Difco) at 2, 4, 6, 9, 29, 30, 35 and $37^{\circ} \mathrm{C}$. Carbon source utilization was tested on medium containing $0.2 \mathrm{~g} \mathrm{NaNO}_{3}, 0.2 \mathrm{~g} \mathrm{NH}_{4} \mathrm{Cl}, 0 \cdot 05 \mathrm{~g}$ yeast extract (Difco) and $0.4 \%(\mathrm{w} / \mathrm{v})$ carbon source in 1 litre artificial sea water as described by Nedashkovskaya et al. (2003). The following carbon sources were examined: arabinose, glucose, lactose, raffinose, sucrose, inositol, sorbitol, mannitol, rhamnose, salicin, xylose and adonitol.

Phenotypic analysis showed that the organism had characteristics reported for genera of the family Flavobacteriaceae: it was Gram-negative, strictly aerobic, oxidase- and catalase-positive, did not produce $\mathrm{H}_{2} \mathrm{~S}$ or indole and was weakly positive for nitrate reduction. Detailed morphological and physiological properties are shown in Table 1 and are given in the species description.

DNA was isolated following the method of Marmur (1961) and the DNA $\mathrm{G}+\mathrm{C}$ content was determined using the thermal denaturation method of Marmur \& Doty (1962). The $\mathrm{G}+\mathrm{C}$ content of the DNA of strain $\mathrm{Fg} 69^{\mathrm{T}}$ was $40 \cdot 4 \mathrm{~mol} \%$.

For analysis of fatty acids, the strain was grown at $28^{\circ} \mathrm{C}$ on marine agar 2216. Cells were harvested after $48 \mathrm{~h}$. Bacterial biomass was treated with $5 \% \mathrm{HCl}$ in methanol at $80{ }^{\circ} \mathrm{C}$ for $180 \mathrm{~min}$ to produce fatty acid methyl esters (FAMEs) (Christie, 1982). FAMEs were analysed by flame-ionization detector (FID)-GC (Shimadzu GC-17) with a fused silica capillary column $(30 \mathrm{~m} \times 0.25 \mathrm{~mm})$, coated with Supelcowax 10 , at $210^{\circ} \mathrm{C}$. Helium was used as a carrier gas. FAMEs were identified by comparing the retention times with those of known standards and using equivalent chain-length measurements. To ensure correct identification, FAMEs were further analysed by GC-MS using a model GCMSQP5050A (Shimadzu) fitted with an MDN-5S capillary column $(30 \mathrm{~m} \times 0.25 \mathrm{~mm})$. The column temperature was programmed as follows: $1 \mathrm{~min}$ hold at $170{ }^{\circ} \mathrm{C}$, followed by an increase to $240{ }^{\circ} \mathrm{C}$ at $2{ }^{\circ} \mathrm{C} \mathrm{min}$ min $^{-1}$ and a hold at $240{ }^{\circ} \mathrm{C}$ for $20 \mathrm{~min}$. The temperature of the injector and detector was $250{ }^{\circ} \mathrm{C}$. The FAMEs formed by the novel organism were (as
Table 1. Major phenotypic characteristics of Salegentibacter species

Strains: 1, S. flavus sp. nov. Fg $69^{\mathrm{T}} ; 2$, S. salegens DSM $5424^{\mathrm{T}} ; 3$, S. holothuriorum KMM $3524^{\mathrm{T}} ; 4$, S. mishustinae KMM $6049^{\mathrm{T}}$. All strains were positive for the following tests: respiratory metabolism, oxidase and catalase activities, hydrolysis of starch and growth at $34{ }^{\circ} \mathrm{C}$ and at $8 \% \mathrm{NaCl}$. All strains were negative for motility by gliding, hydrolysis of agar and cellulose (CM-cellulose and filter paper), acid production from L-arabinose, L-rhamnose, DL-xylose, adonitol, sorbitol, inositol and mannitol and production of indole and acetoin (Voges-Proskauer reaction). Data are from Dobson et al. (1993), McCammon \& Bowman (2000), Nedashkovskaya et al. (2004, 2005) and this study. +, Positive; -, negative; $\mathrm{W}$, weakly positive.

\begin{tabular}{|lcccc|}
\hline Characteristic & $\mathbf{1}$ & $\mathbf{2}$ & $\mathbf{3}$ & $\mathbf{4}$ \\
\hline DNA G+C content $(\mathrm{mol} \%)$ & $40 \cdot 4$ & $36 \cdot 7$ & $36 \cdot 8$ & $37 \cdot 5$ \\
$\mathrm{NaCl}$ required for growth & + & + & - & + \\
Nitrate reduction & - & + & - & - \\
Production of $\mathrm{H}_{2} \mathrm{~S}$ & - & + & + & + \\
Hydrolysis of: & & & & \\
$\quad$ Casein & - & - & - & + \\
Tween 80 & w & + & + & + \\
Gelatin & w & + & + & + \\
$\quad$ Urea & + & - & - & - \\
Growth at $37^{\circ} \mathrm{C}$ & - & - & + & - \\
Growth at $12 \% \mathrm{NaCl}$ & - & + & - & + \\
\end{tabular}

percentages of whole-cell fatty acids): $\mathrm{C}_{12: 0}(1 \cdot 2 \%)$, iso$\mathrm{C}_{14: 0}(1 \cdot 5 \%), \mathrm{C}_{14: 0}(2 \cdot 7 \%)$, iso- $\mathrm{C}_{15: 0}(5 \cdot 4 \%)$, anteiso$\mathrm{C}_{15: 0}(11 \cdot 1 \%)$, iso- $\mathrm{C}_{15: 1}(5 \cdot 4 \%), \mathrm{C}_{15: 0}(8 \cdot 6 \%), \mathrm{C}_{15: 1} \omega 6$ $(2 \cdot 9 \%)$, iso- $\mathrm{C}_{16: 0}(7 \cdot 7 \%)$, anteiso- $\mathrm{C}_{16: 1}(3 \cdot 5 \%), \mathrm{C}_{16: 0}$ $(5 \cdot 0 \%), \mathrm{C}_{16: 1} \omega 7(5 \cdot 1 \%), \mathrm{C}_{16: 1} \omega 9(2 \cdot 4 \%)$, iso- $\mathrm{C}_{17: 1}$ $(1 \cdot 8 \%)$, anteiso- $\mathrm{C}_{17: 1}(1 \cdot 2 \%), \mathrm{C}_{17: 0}(0 \cdot 6 \%), \mathrm{C}_{17: 1} \omega 6$ $(2 \cdot 8 \%), \mathrm{C}_{17: 1} \omega 8(1 \cdot 5 \%), \mathrm{C}_{18: 0}(1 \cdot 8 \%), \mathrm{C}_{18: 1} \omega 9(1 \cdot 7 \%)$, $\mathrm{C}_{14: 0} 3-\mathrm{OH}(0 \cdot 6 \%)$, iso- $\mathrm{C}_{15: 0} 2-\mathrm{OH}(3 \cdot 6 \%)$, anteiso- $\mathrm{C}_{15: 0}$ $2-\mathrm{OH}(3 \cdot 2 \%)$, iso- $\mathrm{C}_{15: 0} 3-\mathrm{OH}(1 \cdot 0 \%)$, iso- $\mathrm{C}_{16: 0} 2-\mathrm{OH}$ $(4 \cdot 3 \%)$, iso- $\mathrm{C}_{16: 0} 3-\mathrm{OH}(6 \cdot 0 \%)$, iso- $\mathrm{C}_{17: 0} 3-\mathrm{OH}(3 \cdot 2 \%)$ and anteiso- $\mathrm{C}_{17: 0} 3-\mathrm{OH}(4 \cdot 4 \%)$. The fatty acid profile of the new isolate exhibited features characteristic of the family Flavobacteriaceae and of the genus Salegentibacter, e.g. the combination of $n-C_{15}$ and $n-C_{16}$ branched-chain saturated and unsaturated cellular fatty acids accounted for 50-70\% of the total. A significantly higher proportion of iso- and anteiso-branched $2-\mathrm{OH}$ and $3-\mathrm{OH} n-\mathrm{C}_{14: 0}$ to $\mathrm{C}_{17: 0}$ fatty acids $\left(26 \%\right.$ in total) was found for strain $\mathrm{Fg} 69^{\mathrm{T}}$ than for S. salegens, S. holothuriorum or $S$. mishustinae (Nedashkovskaya et al., 2004, 2005).

The small-subunit rRNA gene of $\mathrm{Fg} 69^{\mathrm{T}}$ was sequenced (1471 bp) as described elsewhere (Ivanova et al., 2004). The most similar 16S rRNA gene sequences were retrieved using n-BLAST searches (www.ncbi.nlm.nih.gov) and aligned for phylogenetic analysis. Analysis was based on three different approaches: neighbour-joining (Gascuel, 1997), parsimony and maximum-likelihood with global search (from PHYLIP 


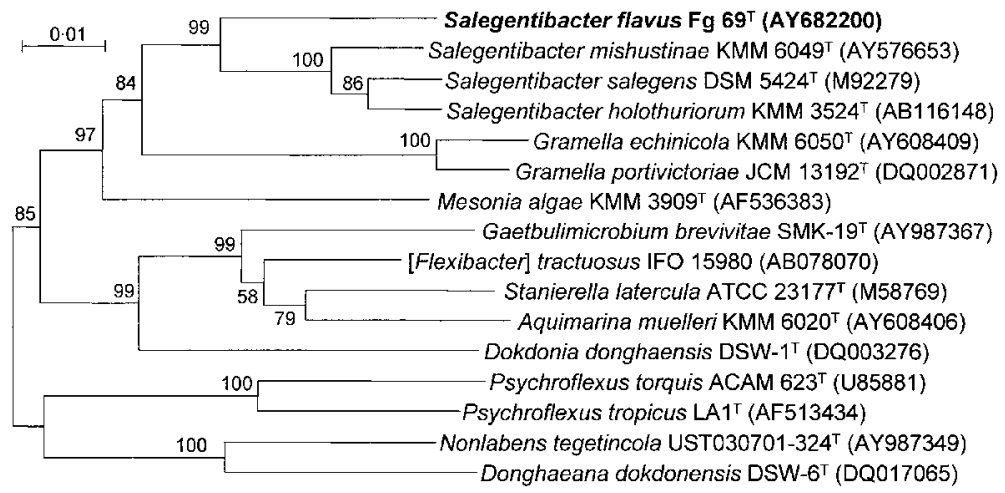

Fig. 1. Phylogenetic position of Salegentibacter flavus sp. nov. according to $16 \mathrm{~S}$ rRNA gene sequence analysis. Unrooted tree resulting from a neighbour-joining analysis as described in the text. Percentages of 1000 bootstrap replications are indicated for branches that were also supported by parsimony and maximum-likelihood $(P<0.01)$ analyses. Bar, 0.01 nucleotide substitutions per position.

version 3.57c; Felsenstein, 1993). The program DNADIST was used to determine sequence similarities using the Kimura two-parameter correction. Finally, a bootstrap analysis (1000 replications) was performed using neighbourjoining (Felsenstein, 1985). 16S rRNA gene sequence analysis revealed that the new isolate clearly belonged to the genus Salegentibacter, as these sequences formed a robust clade (all three methods, bootstrap value of $99.8 \%$; Fig. 1). The $16 \mathrm{~S}$ rRNA gene sequence of strain $\mathrm{Fg} 69^{\mathrm{T}}$ showed $<95 \%$ similarity with those of the three recognized Salegentibacter species. The phylogenetic analysis thus supports the inclusion of Fg $69^{\mathrm{T}}$ within the genus Salegentibacter, while the low level of $16 \mathrm{~S}$ rRNA gene sequence similarity indicates that it represents a novel species.

Strain $\mathrm{Fg} 69^{\mathrm{T}}$ can be readily distinguished from other Salegentibacter species by the combination of the following features: ranges of salinity and temperature for growth, inability to reduce nitrate, to hydrolyse casein and to produce $\mathrm{H}_{2} \mathrm{~S}$ and ability to hydrolyse urea and to hydrolyse Tween 80 weakly (Table 1). Thus, the results indicate that Fg $69^{\mathrm{T}}$ should be classified as the type strain of a novel species within the genus Salegentibacter, for which we propose the name Salegentibacter flavus sp. nov.

\section{Description of Salegentibacter flavus sp. nov.}

Salegentibacter flavus (fla'vus. L. masc. adj. flavus golden yellow).

Cells are Gram-negative, microaerophilic, chemo-organotrophic, non-motile, asporogenic rods, $0.5-0.7 \mathrm{~mm}$ wide and 2.5-4.0 $\mathrm{mm}$ long. Oxidase- and catalase-positive. Colonies are circular, 1-3 $\mathrm{mm}$ in diameter and of low convexity when grown on marine agar 2216. Produces non-diffusible yellow pigment. Flexirubin-type pigments are absent. No growth is detected at 8 or $37^{\circ} \mathrm{C}$. Optimal temperature for growth is $22-25^{\circ} \mathrm{C}$. The $\mathrm{pH}$ range for growth is $5 \cdot 0-10 \cdot 0$, with optimal growth between $\mathrm{pH} 8 \cdot 0$ and $8 \cdot 5$. Growth occurs between 3 and $10 \% \mathrm{NaCl}$, with optimal growth at $3 \% \mathrm{NaCl}$. No growth is observed without $\mathrm{Na}^{+}$. Starch, gelatin and urea are hydrolysed and Tween 80 is weakly hydrolysed. Does not decompose cellulose (CM-cellulose or filter paper), agar or casein. $\mathrm{H}_{2} \mathrm{~S}$, indole and acetoin (Voges-Proskauer reaction) are not produced. Nitrate reduction is negative. Does not utilize citrate, arabinose, glucose, lactose, raffinose, sucrose, inositol, sorbitol, mannitol, rhamnose, salicin, xylose or adonitol. Major cellular fatty acids are iso- $\mathrm{C}_{15: 0}$, anteiso- $\mathrm{C}_{15: 0}, \mathrm{C}_{15: 0}$, iso- $\mathrm{C}_{16: 0}, \mathrm{C}_{16: 0}$ and a range of $\mathrm{C}_{14: 0}$ to $\mathrm{C}_{17: 0}$ hydroxy fatty acids (about $64 \%$ ). The DNA G $+\mathrm{C}$ content is $40 \cdot 4 \pm 0 \cdot 5 \mathrm{~mol} \%$.

The type strain, strain Fg $69^{\mathrm{T}}\left(=\mathrm{KMM} 6000^{\mathrm{T}}=\mathrm{CIP} 107843^{\mathrm{T}}\right)$, was isolated from sediments from Chazhma Bay, Sea of Japan.

\section{Acknowledgements}

This study was partially supported by funds from the Australian Research Council (ARC), grants (State contracts) from the Federal Agency for Science and Innovations of the Ministry for Education and Science of the Russian Federation 'KMM' and 'Scientific Schools', grant 05-04-48211 from the Russian Foundation for Basic Research and grants from the Presidium of the Russian Academy of Sciences 'Molecular and Cell Biology'.

\section{References}

Azegami, K., Nishiyama, K., Watanabe, Y., Kadota, I., Ohuchi, A. \& Fukazawa, C. (1987). Pseudomonas plantarii sp. nov., the causal agent of rice seeding blight. Int J Syst Bacteriol 37, 144-152.

Bernardet, J.-F., Nakagawa, Y. \& Holmes, B. (2002). Proposed minimal standards for describing new taxa of the family Flavobacteriaceae and emended description of the family. Int J Syst Evol Microbiol 52, 1049-1070.

Christie, W. W. (1982). Lipid Analysis. Isolation, Separation, Identification and Structural Analysis of Lipids. Oxford: Pergamon Press.

Dobson, S. J., Colwell, R. R., McMeekin, T. A. \& Franzmann, P. D. (1993). Direct sequencing of the polymerase chain reaction-amplified 16S rRNA gene of Flavobacterium gondwanense sp. nov. and Flavobacterium salegens sp. nov., two new species from a hypersaline Antarctic lake. Int J Syst Bacteriol 43, 77-83.

Fautz, E. \& Reichenbach, H. (1980). A simple test for flexirubin-type pigments. FEMS Microbiol Lett 8, 87-91.

Felsenstein, J. (1985). Confidence limits on phylogenies: an approach using the bootstrap. Evolution 39, 783-791.

Felsenstein, J. (1993). PHYLIP - Phylogenetic Inference Package, version 3.5c. Distributed by the author. Department of Genome Sciences, University of Washington, Seattle, USA. 
Gascuel, O. (1997). BIONJ, an improved version of the NJ algorithm based on a simple method of sequence data. Mol Biol Evol 14, 685-695.

Ivanova, E. P., Kiprianova, E. A., Mikhailov, V. V., Levanova, F. G., Garagulya, A. G., Gorshkova, N. M., Yumoto, N. \& Yoshikawa, S. (1996). Characterization and identification of marine Alteromonas nigrifaciens strains and emendation of the description. Int J Syst Bacteriol 46, 223-228.

Ivanova, E. P., Gorshkova, N. M., Sawabe, T. \& 8 other authors (2004). Sulfitobacter delicatus sp. nov. and Sulfitobacter dubius sp. nov., respectively from a starfish (Stellaster equestris) and sea grass (Zostera marina). Int J Syst Evol Microbiol 54, 475-480.

Ivanova, E. P., Gorshkova, N. M., Mikhailov, V. V. \& 8 other authors (2005). Distribution of saprophytic bacteria in the atomic submarine accident zone in Chazhma Bay, Sea of Japan. Russ J Mar Biol (English translation of Biol Morya) 31, 65-72.

Marmur, J. (1961). A procedure for the isolation of deoxyribonucleic acid from microorganisms. J Mol Biol 3, 208-218.

Marmur, J. \& Doty, P. (1962). Determination of the base composition of deoxyribonucleic acid from its thermal denaturation temperature. J Mol Biol 5, 109-118.

McCammon, S. A. \& Bowman, J. P. (2000). Taxonomy of Antarctic Flavobacterium species: description of Flavobacterium gillisiae sp. nov., Flavobacterium tegetincola sp. nov., and Flavobacterium xanthum sp. nov., nom. rev. and reclassification of [Flavobacterium] salegens as Salegentibacter salegens gen. nov., comb. nov. Int J Syst Evol Microbiol 50, 1055-1063.

McMeekin, T. A., Patterson, J. T. \& Murray, J. G. (1971). An initial approach to the taxonomy of some gram-negative yellow pigmented rods. J Appl Bacteriol 34, 699-716.

Nedashkovskaya, O. I., Suzuki, M., Vysotskii, M. V. \& Mikhailov, V. V. (2003). Vitellibacter vladivostokensis gen. nov., sp. nov., a new member of the phylum Cytophaga-Flavobacterium-Bacteroides. Int J Syst Evol Microbiol 53, 1281-1286.

Nedashkovskaya, O. I., Suzuki, M., Vancanneyt, M., Cleenwerck, I., Zhukova, N. V., Vysotskii, M. V., Mikhailov, V. V. \& Swings, J. (2004). Salegentibacter holothuriorum sp. nov., isolated from the edible holothurian Apostichopus japonicus. Int J Syst Evol Microbiol 54, 1107-1110.

Nedashkovskaya, O. I., Kim, S. B., Lysenko, A. M., Mikhailov, V. V., Bae, K. S. \& Kim, I. S. (2005). Salegentibacter mishustinae sp. nov., isolated from the sea urchin Strongylocentrotus intermedius. Int J Syst Evol Microbiol 55, 235-238.

Smibert, R. M. \& Krieg, N. R. (1994). Phenotypic characterization. In Methods for General and Molecular Bacteriology, pp. 607-654. Edited by P. Gerhardt. Washington, DC: American Society for Microbiology. 